\title{
Horse Chestnut (Aesculus hippocastanum L.) Urban Habitat - Pollution Influence on Some Phenotypic and Morphological Characteristics
}

\section{Fran Poštenjak}

Matije Gupca 6

Jastrebarsko, Croatia

fran.postenjak@gmail.com

\section{Abstract}

Background and purpose: Horse chestnut (Aesculus hippocastanum L.) may be found in most urban areas in Croatia. Over the years it showed to be resistant to various negative urban influences. In this research we tested trees on randomly selected streets with intense traffic in smaller towns. The main goal of this research was to establish the link between pollution and tree growth and to analyze to what extent pollution influences the increase in the measured parameters.

Materials and methods: The research was done in 7 settlements, in towns with the population of up to 75000 inhabitants. The measured parameters were the morphological characteristics of trees, shoots, leaves and nuts. From the selected branches we measured the annual shoot (thickness and length), leaves, the number of flowers and nuts. The crown transparency was assessed according to the ICP Forest method.

Results and conclusions: The phenotype of the urban Horse chestnut significantly differs from its natural phenotype, and it is transformed by multiple radical pruning, what may be seen in the following ratios: the diameter at breast height - tree height, trunk height - tree height, crown height - tree height, crown width - crown height. The most significant characteristic of the tree is the vitality expressed by crown-damage classes. On the selected trees the worst crown damage class was " $3 b$ " and the best was " 0 ". The measured parameters of yearly shoot characteristics were defined. All measured parameters (trees, shoots, leafs and nuts) show significant differences from the given average values.

Keywords: Horse chestnut, phenotype, crown transparency, shoot, leaf and nut morphological characteristics

\section{INTRODUCTION}

Common, Horse chestnut's (Aesculus hippocastanum L.) natural habitat is Central Europe - from Bulgaria to Greece [1]. The tree grows up to $25 \mathrm{~m}$ in height and $100 \mathrm{~cm}$ in diameter at breast height (DBH) during its two-hundred-years life cycle. The species has intense juvenile height growth. It is very sensitive and highly demanding to chemical, physical and biological stand parameters, such as the soil parameters, especially humus, while less demanding to insolation and temperature [2].

In Croatia, Horse chestnut trees may be found in urban areas, parks and alleys in all three regions: the Pannonian, Dinaric and the Mediterranean [3]. The reason for planting horse chestnuts as one of the main urban species lies in the exceptional aesthetics and management characteristics. Although the tree is very tolerant to environmental factors, it is exposed to new pressures of technological advancement, which is especially evident in urban areas.

Horse chestnut is very sensitive to soil quality, especially its chemical, biological and physical characteristics. Horse chestnut physiology is greatly affected by humus as one of the main influences on growth and development (stand devastation may decrease development up to $50 \%$ ) $[4,5]$.

That was the reason why we analyzed the link to environment pollution, its influence on Horse chestnut growth and we attempted to determine the effects on annual shoot, leaf and nut growth. The main goal of this research was to establish the link between pollution and tree growth and to analyze to what extent pollution influences the increase in the measured parameters. 


\section{MATERIALS AND METHODS}

In the research of annual shoot and leaf morphological characteristics the following criteria for tree selection were applied:

- Trees from all three regions: Pannonian, Dinaric and Mediterranean towns with populations of up to 75000 inhabitants;

- Trees near heavy traffic junctions;

- Trees more than 30 years old and not pruned for 5 years (to avoid tree reactions after pruning and the influence of stress on the increase of the measured tree parameters).

In this analysis of air, soil, leaves and nuts, facts that would give us a more complete picture of the devastation and environmental pressure, were not considered due to high costs, so this research should be taken as a preliminary study.

The selected Horse chestnut trees were wider than $25 \mathrm{~cm}$ and the analyzed branches were taken from the crowns' southern exposure. The sampling was done from the crowns' southern exposure, so that equable samples may provide us with representative results, with data free of various physiological reactions / morphological adjustments (e.g. bigger shaded leaves, lesser number of buts due to flower devastation caused by high amounts of sun and ultraviolet radiation). Other measured parameters were trunk diameter (DBH), trunk height, trunk length, crown height, crown width, the crown degree of defoliation and stand microenvironment characteristics. From the selected branches we measured the annual shoot (thickness and length), leaves, number of flowers and nuts.

Crown transparency was assessed according to the ICP Forest method (International Co-operative Programme in Assessment and Monitoring of Air Pollution Effects on Forests) [6].

Research was done in 7 settlements:

- the Pannonian region: Ilok, Vinkovci, Varaždin,

Jastrebarsko and Karlovac;

- the Dinaric region: Razloge;

- the Mediterranean region: Imotski.

llok $\left(45^{\circ} 10^{\prime} \mathrm{N}, 19^{\circ} 28^{\prime} \mathrm{E}\right)$ is a small and the farthest eastern Croatian town. It is situated at approximately 150 meters above the sea level (MAMSL) in the Pannonian lowlands, has a population of around 8300 inhabitants. One tree near the main road was selected for testing.

Vinkovci $\left(45^{\circ} 17^{\prime} \mathrm{N}, 18^{\circ} 48^{\prime} \mathrm{E}\right)$ is a town situated in the eastern part of Croatia in the Pannonian lowlands at approximately 100 MAMSL. It has around 35000 inhabitants and lies on the important traffic corridor that connects Western Europe with the Middle East and Central Europe with the Adriatic Sea. One tree was selected near the main street in Vinkovci.

Varaždin $\left(46^{\circ} 18^{\prime} \mathrm{N}, 16^{\circ} 20^{\prime} \mathrm{E}\right)$ is a city at the edge of the Pannonian lowlands in the northern part of Croatia, at approximately 170 MAMSL. It has around 41000 inhabitants. Two trees that were selected for this study are situated in the town's central park.

Jastrebarsko $\left(45^{\circ} 42^{\prime} \mathrm{N}, 15^{\circ} 40^{\prime} \mathrm{E}\right)$ is a small town near Zagreb, the capital of Croatia, in the North-Western part of Croatia at the edge of the Pannonian lowlands at 154 MAMSL. The Jastrebarsko municipality has around 17000 inhabitants and lies on the strategic corridor connecting the country's inland with the seaside. In our research we included two horse chestnut trees that grow beside the main road on the very compacted and devastated grounds because the space in the vicinity is used as a parking zone.

Karlovac $\left(45^{\circ} 29^{\prime} \mathrm{N}, 15^{\circ} 32^{\prime} \mathrm{E}\right)$ is a city that lies at approximately 112 MAMSL at the border between the Dinaric region and the Pannonian lowlands. The city of Karlovac houses around 60000 inhabitants and lies on the strategic corridor connecting the country's inland with the seaside. Three horse chestnut trees were selected from the city's central park.

Razloge $\left(45^{\circ} 29^{\prime} \mathrm{N}, 14^{\circ} 45^{\prime} \mathrm{E}\right)$ is a small settlement situated in the Dinaric region and a part of the Croatian National Park "Risnjak". This village has 10 permanent inhabitants and lies at approximately 450 MAMSL. One horse chestnut tree from the edge of the village was selected.

Imotski $\left(43^{\circ} 26^{\prime} \mathrm{N}, 17^{\circ} 10^{\prime} \mathrm{E}\right)$ is a small town situated in Dalmatinska zagora at approximately 412 MAMSL. It has around 10500 inhabitants. In our research we included five trees in the main street avenue.

Between the selected settlements there are significant climate differences [7] in cloudiness, precipitation and temperature quoted in Table 1.

\section{RESULTS AND DISCUSSION}

The most significant characteristic of trees is the vitality expressed by tree crown-damage classes, known as crown transparency. The average crown damage class on the tested trees (defoliation) was "1.35", the worst " $3 \mathrm{~b}$ " and the best " 0 ".

Horse chestnut trees significantly differ, not only in the habitat's climate characteristics but also regarding the tree measuring parameters (Table 2 ). 
TABLE 1

Climate parameters in the settlements included in the research

\begin{tabular}{|c|c|c|c|c|c|c|c|}
\hline Climate parameter & Imotski & Razloge & Karlovac & Jastrebarsko & Varaždin & Vinkovci & Ilok \\
\hline avg. annual $\mathrm{T}\left({ }^{\circ} \mathrm{C}\right)$ & 13.8 & 7.7 & 11.0 & 11.0 & 10.0 & 11.2 & 11.7 \\
\hline avg. T spring $\left({ }^{\circ} \mathrm{C}\right)$ & 12.4 & 6.5 & 11.0 & 11.0 & 10.0 & 11.2 & 10.5 \\
\hline avg. T summer $\left({ }^{\circ} \mathrm{C}\right)$ & 22.7 & 16.0 & 20.4 & 20.4 & 21.2 & 20.8 & 21.0 \\
\hline avg. T autumn $\left({ }^{\circ} \mathrm{C}\right)$ & 14.6 & 8.1 & 11.3 & 11.3 & 10.3 & 11.6 & 12.4 \\
\hline avg. T winter $\left({ }^{\circ} \mathrm{C}\right)$ & 5.7 & -0.2 & 1.5 & 1.5 & 0.5 & 1.2 & 2.0 \\
\hline abs. annual max. $\left({ }^{\circ} \mathrm{C}\right)$ & 38.0 & 34.0 & 42.4 & 42.4 & 39.3 & 39.0 & 39.8 \\
\hline abs. annual min. $\left({ }^{\circ} \mathrm{C}\right)$ & -12.0 & -25.0 & -25.2 & -25.2 & -28.0 & -28.8 & -22.0 \\
\hline avg. $\mathrm{N}$ icy days & 0.3 & 17.3 & 8.6 & 8.6 & 14.1 & 11.0 & 8.0 \\
\hline avg. $\mathrm{N}$ chill days & 2.4 & 31.2 & 15.6 & 15.6 & 19.6 & 15.8 & 18.2 \\
\hline avg. $\mathrm{N}$ cold days & 28.1 & 116.8 & 82.8 & 82.8 & 97.1 & 74.9 & 67.2 \\
\hline avg. N warm days & 103.7 & 22.8 & 84.8 & 84.8 & 68.9 & 93.3 & 92.3 \\
\hline avg. N hot days & 46.4 & 1.8 & 23.9 & 23.9 & 12.6 & 27.8 & 26.8 \\
\hline avg. annual RH (\%) & 60 & 86 & 77 & 77 & 77 & 77 & 71 \\
\hline $\begin{array}{l}\text { avg. annual } \\
\text { precipitation }(\mathrm{mm})\end{array}$ & 1310 & 2486 & 1121 & 1121 & 888 & 687 & 764 \\
\hline $\begin{array}{l}\text { avg. annual precipitation } \\
\text { - spring }(\mathrm{mm})\end{array}$ & 265 & 518 & 248 & 248 & 190 & 171 & 188 \\
\hline $\begin{array}{l}\text { avg. annual precipitation } \\
\text { - summer }(\mathrm{mm})\end{array}$ & 147 & 428 & 284 & 284 & 302 & 203 & 240 \\
\hline $\begin{array}{l}\text { avg. annual precipitation } \\
\text { - autumn }(\mathrm{mm})\end{array}$ & 443 & 744 & 311 & 311 & 239 & 153 & 171 \\
\hline $\begin{array}{l}\text { avg. annual precipitation } \\
\text { - winter }(\mathrm{mm})\end{array}$ & 455 & 786 & 278 & 278 & 160 & 157 & 165 \\
\hline $\begin{array}{l}\text { avg. } N \text { day precipitation } \\
>20(\mathrm{~mm})\end{array}$ & 19.9 & 46.5 & 13.9 & 13.9 & 10.9 & 6.8 & 8.2 \\
\hline avg. $\mathrm{N}$ day snow $>0,1(\mathrm{~mm})$ & 7.7 & 45.7 & 25.7 & 25.7 & 25.0 & 21.7 & 23.8 \\
\hline $\begin{array}{l}\text { avg. } N \text { day snow on ground } \\
>1(\mathrm{~cm})\end{array}$ & 8.6 & 82.8 & 39.8 & 39.8 & 43.3 & 26.4 & 29.1 \\
\hline avg. annual cloudiness & 5.1 & 6.6 & 6.2 & 6.2 & 6.2 & 5.2 & 6.0 \\
\hline avg. $\mathrm{N}$ cloudy days & 105.7 & 171.9 & 135.0 & 135.0 & 131.7 & 110.3 & 141.2 \\
\hline avg. $\mathrm{N}$ clear days & 103.4 & 56.4 & 54.7 & 54.7 & 51.9 & 99.3 & 64.4 \\
\hline
\end{tabular}

avg. - average; abs. - absolute; $T$ - temperature; $N$ - number

\section{TABLE 2}

The selected Horse chestnut tree measurement parameters

\begin{tabular}{|l|c|c|c|c|c|c|c|c|}
\hline $\begin{array}{c}\text { Tree measurement } \\
\text { parameter }\end{array}$ & Ilok & Vinkovci & Varaždin & Jastrebarsko & Karlovac & Razloge & Imotski & Average \\
\hline $\begin{array}{l}\text { Diameter at breast } \\
\text { height "DBH" (cm) }\end{array}$ & 48 & 47 & 41 & 41 & 58 & 52 & 35 & 46 \\
\hline Tree height „h" (m) & 15.5 & 11.5 & 12.5 & 9.5 & 25.5 & 18.5 & 9.8 & 14.6 \\
\hline Trunk length „hd" (m) & 5.0 & 4.8 & 5.0 & 2.5 & 7.0 & 4.5 & 3.4 & 4.6 \\
\hline Crown height "L" (m) & 10.5 & 6.7 & 7.5 & 7.0 & 18.5 & 14.0 & 3.7 & 9.7 \\
\hline Crown width „S" (m) & 5.8 & 7.9 & 8.1 & 7.2 & 8.7 & 8.6 & 7.7 & 7.7 \\
\hline Defoliation & $1 \mathrm{~b}$ & $1 \mathrm{~b}$ & $1 \mathrm{~b}$ & $3 \mathrm{~b}$ & $1 \mathrm{~b}$ & 0 & $1 \mathrm{a}$ & 1.35 \\
\hline Ratio DBH/h & 0.031 & 0.041 & 0.033 & 0.043 & 0.023 & 0.028 & 0.036 & 0.034 \\
\hline Ratio hd/h & 0.322 & 0.417 & 0.400 & 0.263 & 0.275 & 0.243 & 0.347 & 0.324 \\
\hline Ratio L/h & 0.677 & 0.583 & 0.600 & 0.737 & 0.725 & 0.757 & 0.378 & 0.637 \\
\hline Ratio S/L & 0.552 & 1.179 & 1.080 & 1.029 & 0.470 & 0.614 & 2.081 & 1.001 \\
\hline
\end{tabular}




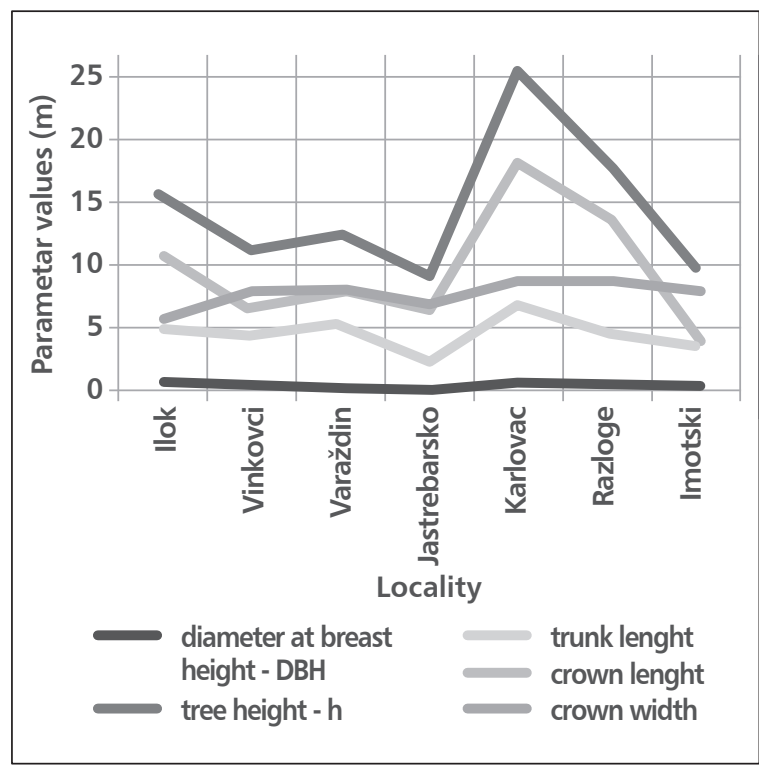

FIGURE 1

Important tree measuring parameters of the selected Horse chestnut trees

The selected trees differed mostly in tree height while the least differences were found in crown width (Graph 1). Differences were evident also in the relation between crown width and crown length, the least differences in the $\mathrm{DBH} /$ tree height ratio (Graph 2).

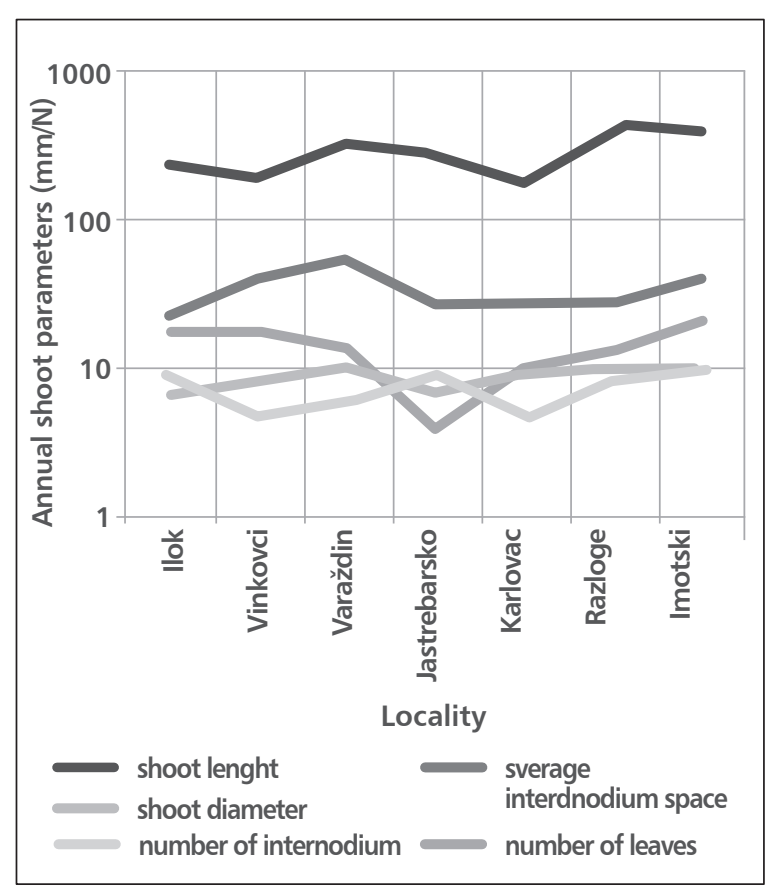

FIGURE 3

Horse chestnut annual shoot parameters

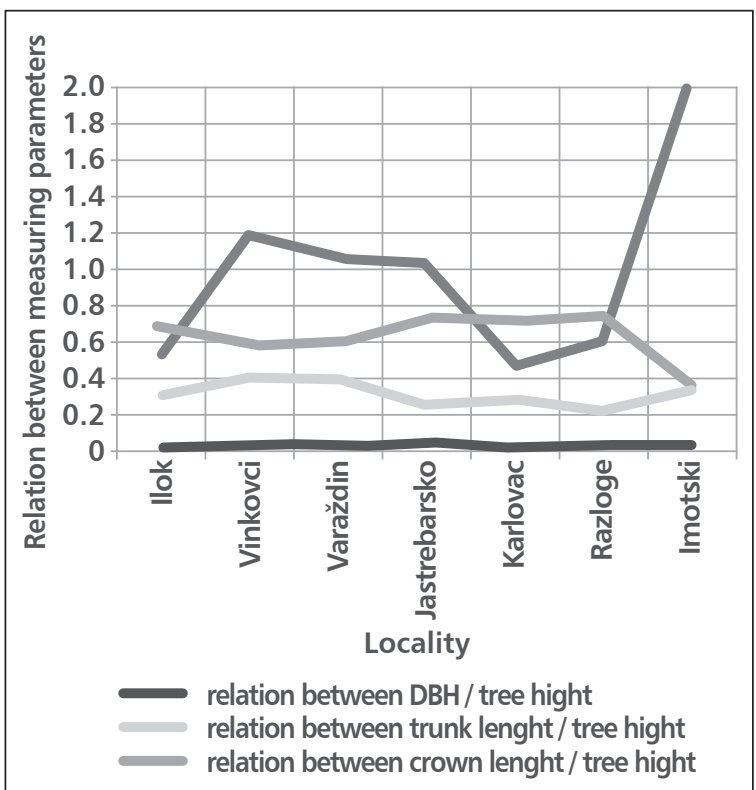

\section{FIGURE 2}

Relations of the Horse chestnut tree measuring parameters

The results of the measured annual shoot parameters are displayed in Table 3 . The greatest difference was recorded in the number of leaves and the least difference in the annual shoot diameter (Graph 3).

The measured leaf parameters are displayed in Table 4, the longest leaf was recorded in Razloge and the shortest in Jastrebarsko. Also the leaves in Jastrebarsko

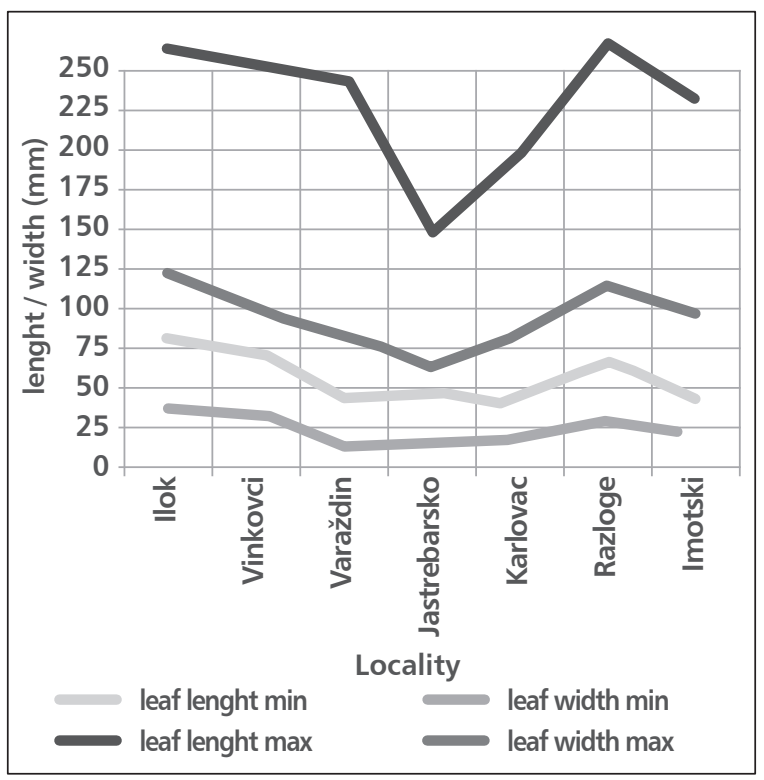

FIGURE 4

Horse chestnut leaf parameters 
TABLE 3

Horse chestnut annual shoot parameters

\begin{tabular}{|l|c|c|c|c|c|c|}
\hline \multirow{2}{*}{ Settlement } & \multicolumn{2}{|c|}{ Shoot $(\mathrm{mm})$} & \multirow{2}{*}{$\begin{array}{c}\text { Number of } \\
\text { internodium }\end{array}$} & $\begin{array}{c}\text { Internodium } \\
\text { space }(\mathrm{mm})\end{array}$ & $\begin{array}{c}\text { Number } \\
\text { of leaves }\end{array}$ & $\begin{array}{c}\text { Number } \\
\text { of flowers }\end{array}$ \\
\cline { 2 - 6 } Ilok & length & diameter & 9 & 22.62 & 18 & 0.5 \\
\hline Vinkovci & 229.50 & 6.54 & 5 & 40.80 & 18 & - \\
\hline Varaždin & 339.10 & 10.50 & 6 & 56.51 & 14 & - \\
\hline Jastrebarsko & 279.70 & 7.17 & 9 & 27.25 & 4 & 1 \\
\hline Karlovac & 191.17 & 9.23 & 5 & 29.17 & 10 & 1 \\
\hline Razloge & 412.10 & 10.20 & 9 & 28.81 & 14 & 1 \\
\hline Imotski & 410.05 & 10.08 & 10 & 41.70 & 22 & 0.5 \\
\hline Average & 315.86 & 9.03 & 8.43 & 38.25 & 14.57 & 0.75 \\
\hline
\end{tabular}

had the least width while the leaves measured in llok were the widest (Graph 4). The longest petiole was measured in Imotski and the shortest in Jastrebarsko.

The phenotype of the urban horse chestnut tree significantly differs from its natural phenotype, and it is transformed with multiple radical pruning - what may be seen in the following ratios: (I) DBH - tree height (average 0.034), (II) trunk height - tree height (average 0.324), (III) crown height - tree height (average 0.637), (IV) crown width - crown height (average 1.001).

Horse chestnut is a species found in forests of Central Europe, but it has adapted very well to urban environment. In Croatia it may be found in all 3 regions, but it prefers the mild climate in the continental part of the country.

The urban soil devastation and destruction, especially of its humus layer, has been present and ongoing for more than half a century [8], and negatively influencing the growth and tree development - up to $50 \%$ growth reduction [5]. The global and local pollution (soil, water and air), especially the continuous traffic and transportation pollution (for more than half a century), has a negative influence on tree growth [5].

Those chestnuts in Jastrebarsko grow near the main road, in the town's centre and represent trees mostly influenced by traffic pollution pressure and stand devastation, with theclass " $3 \mathrm{~b}$ " crowndamage, whilethe tree in Razloge is least influenced by pollution pressure. It has class " 0 " crown defoliation damage, evident from the tree measurement parameters and the morphological parameters analyzed in this research.

The research showed that in a relatively unpolluted habitat the leaf and annual shoot size are greater than in the habitat with intense pollution, where annual shoot and leaves are significantly lesser.

\section{TABLE 4}

Horse chestnut leaf parameters

\begin{tabular}{|l|c|c|c|c|c|c|c|c|}
\hline \multirow{2}{*}{ Settlement } & \multicolumn{4}{|c|}{ Leaf } & \multicolumn{4}{c|}{ Petiole } \\
\cline { 2 - 9 } & \multicolumn{2}{|c|}{ length } & \multicolumn{2}{c|}{ width } & \multicolumn{2}{c|}{ length } & \multicolumn{2}{c|}{ diameter } \\
\cline { 2 - 9 } & $\min$ & $\max$ & $\min$ & $\max$ & $\min$ & $\max$ & $\min$ & $\max$ \\
\cline { 2 - 9 } & $\mathrm{mm}$ & $\mathrm{mm}$ & $\mathrm{mm}$ & $\mathrm{mm}$ & $\mathrm{mm}$ & $\mathrm{mm}$ & $\mathrm{mm}$ & $\mathrm{mm}$ \\
\hline Ilok & 82.36 & 263.35 & 34.86 & 121.41 & 27.65 & 169.95 & 1.53 & 6.36 \\
\hline Vinkovci & 72.81 & 252.35 & 35.21 & 99.22 & 40.05 & 238.25 & 1.98 & 7.82 \\
\hline Varaždin & 44.50 & 244.15 & 14.70 & 84.25 & 17.95 & 204.80 & 0.75 & 3.30 \\
\hline Jastrebars & 48.15 & 148.70 & 14.20 & 64.25 & 18.30 & 117.75 & 0.66 & 1.85 \\
\hline Karlovac & 41.98 & 198.48 & 16.60 & 82.18 & 13.13 & 157.28 & 0.63 & 3.05 \\
\hline Razloge & 68.17 & 269.25 & 29.30 & 114.20 & 34.73 & 188.65 & 2.13 & 5.64 \\
\hline Imotski & 46.24 & 233.25 & 22.52 & 99.18 & 27.84 & 289.30 & 1.36 & 3.43 \\
\hline Average & 74.89 & 232.79 & 31.06 & 94.96 & 37.09 & 196.60 & 1.56 & 4.46 \\
\hline
\end{tabular}




\section{CONCLUSIONS}

Based on the research done on annual horse chestnut shoots, the following conclusions may be made:

- The sampled horse chestnut tree locations differ in basic meteorological parameters;

- The selected trees immediate environment differs significantly regarding the traffic intensity from the lowest intensity in Razloge to the most intense traffic in Jastrebarsko;

- The sampled horse chestnut trees, differ signifi- cantly based on the basic measuring tree parameters. Those differences are evident in crown transparency, that is, the tree in Razloge has the best, class " 0 ", crown damage and the trees in Jastrebarsko the worst crown damage, class " $3 \mathrm{~b}$ ";

- The traffic pollution pressure on the environment is the highest in Jastrebarsko, and that is reflected in the reduced horse chestnut tree morphological and tree measuring parameters, while on the other hand the horse chestnut tree in Razloge has the best morphological and tree measuring parameters.

\section{REFERENCES}

1. BORZAN Ž 2001 Imenik drveća i grmlja. Hrvatske šume, p.o. Zagreb, Zagreb, p 485

2. HERMAN J 1971 Šumarska dendrologija. Stanbiro, Zagreb, p 470

3. CESTAR D 1974 Razdjeljenje SR Hrvatske na tipološke jedinice. Bilten 5, Zagreb, p 18

4. ŠAFAR J 1963 Ekonomski i biološki temelji za uzgajanje šuma. Savez šumarski društava Hrvatske, Zagreb, p 598
5. MARTINOVIĆ J 1997 Tloznanstvo u zaštiti okoliša priručnik za inženjere. Zagreb, p 276

6. UN ECE 1994 Manual on methods and criteria for harmonized sampling, assessment, monitoring and analysis of the effects of air pollution on forests. Programme Coordinating Centres, Hamburg and Prague, p 177

7. BERTOVIĆ S Klimatski podaci SR Hrvatske, Republički hidrometeorološki zavod SR Hrvatske, Zagreb, p 127

8. GLAVAČ V 1999 Uvod u globalnu ekologiju, Zagreb, p 211 